http://journal.nafo.int

J. Northw. Atl. Fish. Sci., Vol. 6: 21-35

\title{
Larval Abundance and Mortality of Atlantic Herring (Clupea harengus L.) Spawned in the Georges Bank and Nantucket Shoals Areas, 1971-78 Seasons, in Relation to Spawning Stock Size*
}

\author{
R. Gregory Lough, George R. Bolz, Michael Pennington and Marvin D. Grosslein \\ National Marine Fisheries Service, Northeast Fisheries Center, \\ Woods Hole, Massachusetts, 02543, USA
}

\begin{abstract}
Time of hatching, abundance of recently-hatched larvae and their relative contribution from the Georges Bank and Nantucket Shoals spawning grounds, as well as mortality during the autumn-winter period are estimated for eight spawning seasons on the basis of data from the ICNAF Larval Herring Surveys which were conducted during 1971-78. Indices show that the highest initial larval production occurred in 1973 and 1974 as a result of the large 1970 year-class and that there was a decline in production of about two orders of magnitude by 1976 and thereafter. The collapse of the fishery on Georges Bank in 1976 coincided with a delay in peak spawning from mid- to late-October, a contraction of the spawning season, and a shift of the remaining spawning population to northwestern Georges Bank and Nantucket Shoals. Furthermore, the mean seasonal mortality rate of $5 \%$ per day, estimated over the first 6 months of life, varied significantly (3-7\%/day) after the 1975 season. The initial larval production estimates are compared with abundance indices (age $3+$ herring) from spring bottom-trawl surveys, and sources of bias are evaluated.
\end{abstract}

\section{Introduction}

Surveys of Atlantic herring (Clupea harengus) larvae have been conducted in the Georges Bank-Gulf of Maine region since the 1950's to provide information on seasonality of spawning, location of spawning grounds, and relative size and possible intermixing of the populations (Tibbo et al., 1958; Tibbo and Legaré, 1960; Colton et al., 1961; Marak and Colton, 1961, Marak et al., 1962a, 1962b). Spawning occurs predominantly in autumn on the shoal areas of southwestern Scotian Shelf (Das, 1968, 1972), western Gulf of Maine and Georges Bank (Graham et al., 1972; Graham, 1982). Boyar et al. (1973) summarized the seasonal distribution of larval herring in the Georges Bank-Gulf of Maine region from 1962 to 1970 and concluded that larvae which originated from these three spawning areas are retained in the vicinity of the spawning sites and, for the most part, do not appear to intermix.

With the development of the herring fishery on Georges Bank by distant-water fleets in the 1960's, the herring catch increased rapidly until 1968 and declined thereafter to virtually zero in 1977 , notwithstanding the abundant 1970 year-class (Anthony and Waring, 1980). After 1972, the herring fishery on Georges Bank was heavily dependent on the 1970 year-class which accounted for approximately $80 \%$ of the total herring population on the bank during 1974-77.

Fluctuations in recruitment of herring stocks are believed to be caused chiefly by differential mortality during the first year of life, because there is no clear relationship between recruitment and spawning stock over a wide range of spawning stock size, and because the size of a year-class appears to be fixed within relatively narrow limits by the time herring reach the juvenile stage (Anthony and Waring, 1980). Interest in conservation of Georges Bank herring, and general belief in the hypothesis that success of a year-class is controlled by factors which operate during the larval period, led the International Commission for the Northwest Atlantic Fisheries (ICNAF) to develop a major cooperative research program on the early life history of herring stocks in the Georges Bank-Gulf of Maine region (ICNAF, 1971). The larval herring surveys which began in the autumn of 1971 were designed to measure major annual variations in larval production, dispersal, mortality and growth during the first 6 months of life, with the long-term objective of identifying the mechanisms which control larval survival or, at least, the environmental conditions which are associated with large and small year-classes. An intensive time series of data was collected during surveys of the Georges Bank-Nantucket Shoals area during eight successive autumn-winter periods.

In this paper, abundance and mortality estimates of herring larvae are presented in relation to potential egg production of the spawning stock in the Georges Bank-Nantucket Shoals area for the 1971-78 spawning seasons. This study was conducted as part of the Marine Resources Monitoring, Assessment and Prediction (MARMAP) program of the Northeast Fisheries 
Center, which measures longterm changes in fish stock abundance off the northeastern United States (Sherman, 1980). The results of the study are based primarily on the $0.333-\mathrm{mm}$ mesh bongo-net plankton samples which were sorted at the Polish Plankton Sorting Center, Szczecin, Poland (Sherman and Ejsymont, MS 1976). Preliminary analyses have been made of data from the $0.505-\mathrm{mm}$ mesh plankton samples, which were sorted by researchers of each participating country, and these analyses have been reported previously (L'Herrou and Briand, MS 1972; ICNAF, MS 1972; Schnack and Stobo, MS 1973; Au, MS 1974; Minet et al., MS 1974; Schnack, MS 1974, MS 1975; Balkovoy et al., MS 1975; Grimm et al., MS 1975; Paulmier and Briand, MS 1975; Lough, MS 1976a, 1976b; Colton and Byron, MS 1976; Noskov et al., MS 1977; Joakimsson, MS
1978; Lough and Bolz, MS 1979; Lough et al., 1981; Grimm, 1983). The results of additional survey coverage were reported by Stobo and Iles (MS 1973) for the Bay of Fundy and by Graham et al. (MS 1973) for the western Gulf of Maine.

\section{Materials and Methods}

\section{Field sampling}

A total of 39 larval herring surveys were conducted at various times during 1971-79 by research vessels from Federal Republic of Germany, France, Poland, USSR and USA (Table 1). When the cooperative larval herring surveys were initiated in 1971, the approach

TABLE 1. Summary of 39 larval herring surveys of the Georges Bank-Nantucket Shoals area during the $1971-78$ spawning seasons.

\begin{tabular}{|c|c|c|c|c|c|c|}
\hline \multirow[b]{2}{*}{ Season } & \multirow[b]{2}{*}{ Vessel } & \multirow[b]{2}{*}{ Survey dates } & \multirow{2}{*}{$\begin{array}{c}\text { Area } \\
\text { surveyed } \\
\left(\mathrm{km}^{2}\right)\end{array}$} & \multirow{2}{*}{$\begin{array}{c}\text { Percent } \\
\text { area with } \\
\text { larvae }\end{array}$} & \multicolumn{2}{|c|}{ Samples used } \\
\hline & & & & & 0.333 & 0.505 \\
\hline \multirow[t]{5}{*}{1971} & Cryos & 09-24 Sep & 78,880 & 17.7 & & $x$ \\
\hline & Delaware II & 21 Sep-04 Oct & 82,360 & 26.8 & & $x$ \\
\hline & Viandra & $09-25 \mathrm{Oct}$ & 77,140 & 60.2 & $x$ & \\
\hline & W. Herwig & 28 Oct-12 Nov & 81,200 & 47.1 & $x$ & \\
\hline & Albatross IV & 02-17 Dec & 83,520 & 55.6 & & $x$ \\
\hline \multirow[t]{5}{*}{1972} & Argus & 22-30 Sep & 52,200 & 17.8 & & $x$ \\
\hline & Wieczno & $02-28 \mathrm{Oct}$ & 92,800 & 46.3 & $x$ & \\
\hline & Argus & $12-28$ Oct & 87,000 & 58.7 & & $x$ \\
\hline & Anton Dohrn & 31 Oct-12 Nov & 90,480 & 66.7 & $x$ & \\
\hline & Albatross IV & 02-20 Dec & 93,960 & 61.7 & & $x$ \\
\hline \multirow[t]{6}{*}{1973} & Cryos & 16-28 Sep & 51,040 & 13.6 & $x$ & \\
\hline & Wieczno & 28 Sep-20 Oct & 92,800 & 42.5 & & $x$ \\
\hline & Belogorsk & 15 Oct-01 Nov & 93,960 & 70.4 & $x$ & \\
\hline & W. Herwig & 28 Oct-08 Nov & 92,800 & 77.5 & & $x$ \\
\hline & Albatross IV & 04-20 Dec & 95,120 & 86.6 & $x$ & \\
\hline & Albatross IV & 11-22 Feb 1974 & 66,120 & 54.4 & & $x$ \\
\hline \multirow[t]{5}{*}{1974} & Wieczno & 27 Sep-10 Oct & 96,280 & 24.1 & & $x$ \\
\hline & Prognoz & $18-30 \mathrm{Oct}$ & 91,640 & 72.2 & $x$ & \\
\hline & Anton Dohrn & 16-23 Nov & 81,200 & 81.4 & & $x$ \\
\hline & Albatross IV & 04-19 Dec & 96,280 & 74.7 & $x$ & \\
\hline & Albatross IV & $12-28$ Feb 1975 & 91,640 & 48.1 & $x$ & \\
\hline \multirow[t]{5}{*}{1975} & Belogorsk & 25 Sep-08 Oct & 93,960 & 15.4 & & $x$ \\
\hline & Belogorsk & $17-30 \mathrm{Oct}$ & 95,120 & 60.4 & $x$ & \\
\hline & Anton Dohrn & 01-18 Nov & 100,920 & 70.1 & $x$ & \\
\hline & Albatross IV & 05-17 Dec & 96,280 & 62.7 & $x$ & \\
\hline & Albatross $\mathrm{IV}$ & 10-25 Feb 1976 & 99,760 & 45.4 & $x$ & \\
\hline \multirow[t]{5}{*}{1976} & Belogorsk & $04-11 \mathrm{Oct}$ & 47,560 & 28.1 & $x$ & \\
\hline & Wieczno & 14 Oct-03 Nov & 96,280 & 15.4 & $\mathrm{x}$ & \\
\hline & Anton Dohrn & 15-29 Nov & 96,280 & 20.5 & $x$ & \\
\hline & Researcher & 27 Nov-11 Dec & 84,680 & 31.9 & $x$ & \\
\hline & Mt. Mitchell & 13-24 Feb 1977 & 95,120 & 23.5 & $x$ & \\
\hline \multirow[t]{4}{*}{1977} & Wieczno & 04-24 Oct & 63,800 & 21.8 & $x$ & \\
\hline & Anton Dohrn & 01-18 Nov & 93,960 & 49.4 & $x$ & \\
\hline & Delaware $/ 1$ & $08-20 \mathrm{Dec}$ & 68,440 & 34.8 & & $x$ \\
\hline & Albatross IV & 14 Feb-08 Mar 1978 & 96,280 & 16.9 & $\mathrm{x}$ & \\
\hline \multirow[t]{4}{*}{1978} & Wieczno & 14 Oct-01 Nov & 71,920 & 37.1 & $x$ & \\
\hline & Anton Dohrn & 26 Oct-17 Nov & 83,520 & 9.7 & $x$ & \\
\hline & Albatross IV & 29 Nov-12 Dec & 93,960 & 13.6 & $x$ & \\
\hline & Mt. Mitchell & 15-24 Feb 1979 & 54,520 & 0.0 & & $x$ \\
\hline
\end{tabular}

${ }^{a}$ Bongo sampler with 0.333 and $0.505 \mathrm{~mm}$ mesh nets. 


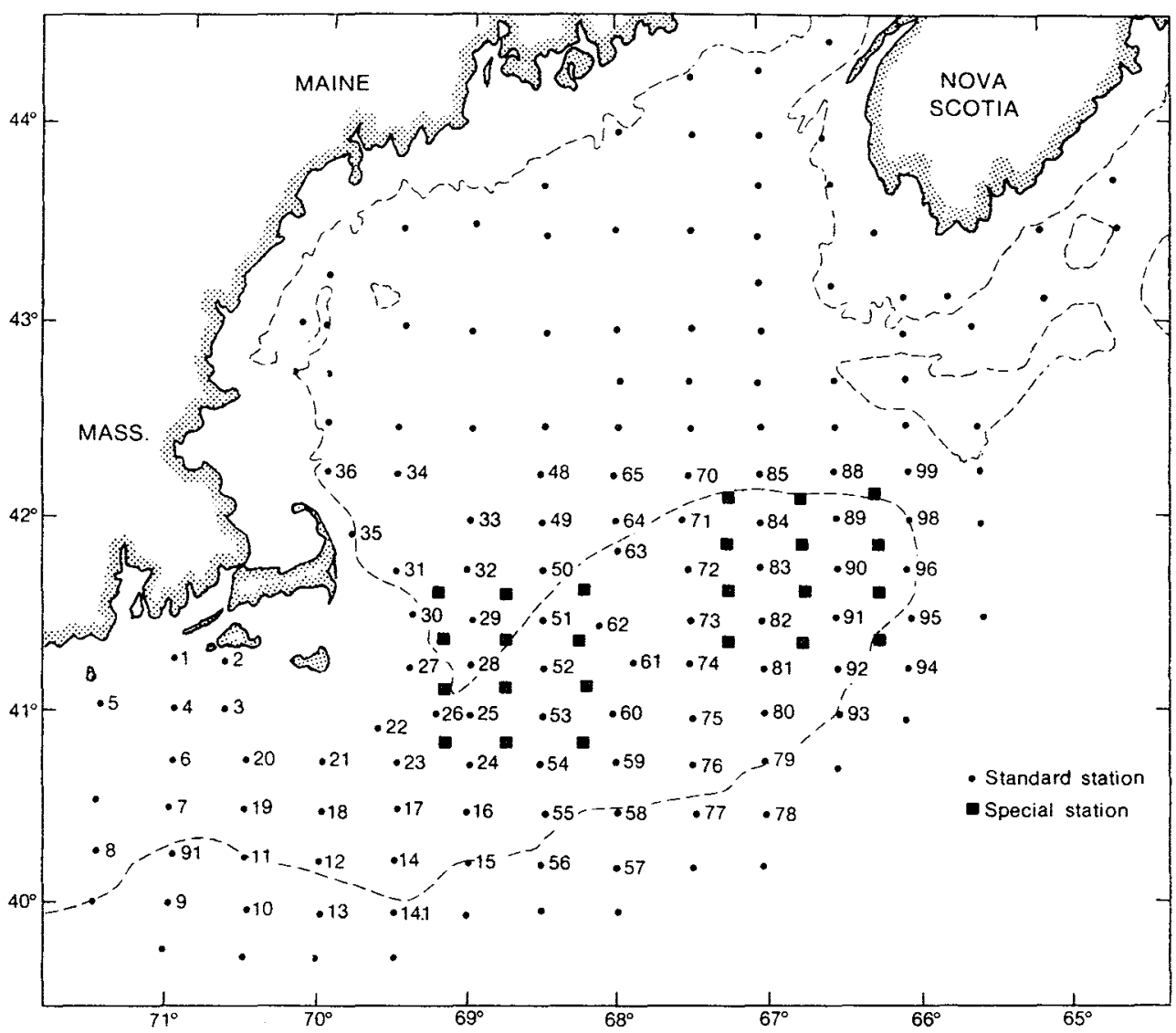

Fig. 1. Locations of stations developed for use during the ICNAF larval herring surveys of the Gulf of MaineGeorges Bank-Nantucket Shoals region, and the subset of numbered stations for which data were utilized in this paper. (Special stations were sometimes sampled in areas of high larval densities. Stations 1-36 represent the Nantucket Shoals area and 48-99 the Georges Bank area.)

was to cover the entire Georges Bank-Gulf of Maine region with a standard grid of sampling stations, which were 15-20 miles $(27-36 \mathrm{~km})$ apart, at least once a month from September to December. However, beginning in 1974, only the Georges Bank-Nantucket Shoals area was emphasized, as indicated by the numbered stations in Fig. 1. In 1974-79, February surveys were conducted by USA vessels to examine overwinter abundance and mortality.

In 1971, the standard procedure at each station, for all vessels except Albatross $\mathrm{V}$, was a double oblique tow at 3.5 knots $(6.5 \mathrm{~km} / \mathrm{hr})$ with a $61-\mathrm{cm}$ bongo sampler containing 0.333 and $0.505 \mathrm{~mm}$ mesh nets (Posgay and Marak, 1980). The gear was deployed at $50 \mathrm{~m} / \mathrm{min}$ to a maximum depth of $200 \mathrm{~m}$ or to within $5 \mathrm{~m}$ of the bottom in shoaler areas. Retrieval was at 20 $\mathrm{m} / \mathrm{min}$ up to a depth of $40 \mathrm{~m}$ and was then changed to stepwise sampling of $202-\mathrm{m}$ steps for $1 \mathrm{~min}$ each. On Albatross $\mathrm{V}$, the sampler was retrieved continuously at $10 \mathrm{~m} / \mathrm{min}$ in the upper $40 \mathrm{~m}$. Beginning in 1972 and continuing to the end of the series, the tow profile was standardized for all vessels, with a maximum depth of tow of $100 \mathrm{~m}$ and continuous retrieval at $10 \mathrm{~m} / \mathrm{min}$. In 1974, when emphasis was placed on sampling the
Georges Bank-Nantucket Shoals area, small bongo samplers (20-cm diameter) with fine-mesh nets were added to the $61-\mathrm{cm}$ bongo array, and more effort was given to studying primary production. Thereafter, sampling was expanded to include a finer grid of plankton stations in areas of large spawning aggregations of herring, more complete hydrographic coverage, and studies of nutrients, chlorophyll and primary production (ICNAF, 1975; Pastuszak et al., 1982; Cohen et al., 1982). Detailed information on sampling methods and survey data was reported by Lough and Bolz (MS 1979).

\section{Sample processing}

All available 0.333 -mesh plankton samples from the surveys were sorted at the Polish Sorting Center for total ichthyoplankton by using standard protocols (Sherman et al., MS 1976a, 1976b). In most cases, all herring larvae were removed from the samples except in a few instances where extremely high densities required subsampling. Standard length (SL) measurements of up to 100 herring larvae per sample were taken to the nearest $0.1 \mathrm{~mm}$ to represent the sample length-frequency distributions. For this study, data from the $0.505-\mathrm{mm}$ mesh samples (14 surveys) were 
substituted for $0.303-\mathrm{mm}$ mesh samples which were lost or had been partially presorted and for which complete data were unavailable (Table 1).

\section{Larval abundance and mortality estimation}

The catch frequencies of larval herring $(1-\mathrm{mm}$ length classes) from each survey were standardized to number per $\mathrm{m}^{2}$ of sea-surface area by the formula.

$$
N=C D / V
$$

where $N$ is the number of larvae per $m^{2}$ of sea-surface by station, $C$ is the catch of larvae, $D$ is the depth of tow $(\mathrm{m})$, and $V$ is the volume of water $\left(\mathrm{m}^{3}\right)$ filtered by the net.

Larval herring lengths were corrected for shrinkage due to net-treatment time and preservation treatment by using Theilacker's (1980) model (which predicts live northern anchovy size):

$$
1.03 \ln L=\ln X_{1}+0.289 \exp \left(-0.434 X_{1} X_{2}{ }^{-0.680}\right)
$$

where $L$ is live size $(\mathrm{mm}), X_{1}$ is standard length $(\mathrm{mm})$ of preserved specimen, and $X_{2}$ is time from death until preservation ( $20 \mathrm{~min}$ ). Theilacker recommended using an additional $3 \%$ shrinkage for all body parts preserved in formalin after net treatment.

An index of the initial abundance of larvae in separate spawning areas of Georges Bank and Nantucket Shoals was made for each season by the method of Schnack (MS 1974). In this case, the middate of the survey of each spawning area was estimated as precisely as possible. Under the assumption of a constant spawning rate, the abundance of small larvae $<12 \mathrm{~mm}$ $\mathrm{SL}$ ) within the spawning area multiplied by the number of survey days provided an index of the initial production of larvae for the sampling period. Further adjustments of the data were made for known errors and biases to provide more accurate abundance estimates of larvae by length classes. Commonly-used fishery techniques were then employed to calculate average seasonal mortality rates. In this case, the Georges Bank-Nantucket Shoals spawning area and season were treated as a unit.

The mean density of larvae of each $1-\mathrm{mm}$ length class was estimated for each survey by methods described by Pennington (1983). The technique, which is based on the delta-distribution (Aitchison and Brown, 1957), has been found to be an efficient method for estimating the mean density of eggs and larvae from surveys containing some zero catches. Unbiased estimators of the arithmetic mean and its variance for the delta-distribution were given by Pennington (1983). In view of the assessment problems that were discussed by the ICES Working Group on Mackerel Egg Surveys (ICES, MS 1984), these estimates were considered to be appropriate for the survey design and methodology.
In order to provide some adjustment of the data for daytime avoidance of the net by large larvae, ratios of night to day abundances were calculated for the $1-\mathrm{mm}$ length classes that were derived from the estimates of mean density. The fitted equation

$$
R=0.22 L-2.20 \quad\left(r^{2}=0.81\right)
$$

where $R$ is the night to day ratio and $L$ is the $1-\mathrm{mm}$ length class, was used to adjust day-station catches of 15-32 $\mathrm{mm}$ larvae in order to make them comparable with the night catches. For estimation of mortality rates, $8-32 \mathrm{~mm}$ larvae were considered to be fully vulnerable to capture by the net.

Estimates of seasonal abundance were made essentially by the expanded day and area method of Sette and Ahlstrom (1948), which assumes that the estimates are representative of the study area and the period of time between adjacent surveys. For each survey within a season (September-February), the mean density of each length class of larvae was multiplied by the number of days represented by the survey and by the total area of Georges Bank-Nantucket Shoals encompassed by the study $\left(99,750 \mathrm{~km}^{2}\right)$. The seasonal abundance estimates of $1-\mathrm{mm}$ length classes of larvae were obtained by summing the survey abundance estimates.

Length-specific mortality rates were estimated for each season, under the assumption that abundance declines exponentially with length by the equation

$$
A_{L}=A_{0} \exp (-Z L)
$$

where $A_{L}$ is abundance of larvae at length $L, A_{0}$ is abundance of larvae at hatching length, $L$ is standard length of live larvae $(\mathrm{mm})$, and $Z$ is the instantaneous mortality coefficient per $\mathrm{mm}$ of standard length. Analysis of covariance techniques were used to determine significant differences in mortality among seasons.

Mortality is best described as a function of age, which can be derived from the abundance-length data if a reasonable growth model is known (Houde, 1977). Mean growth of larval herring was described by Lough et al. (1982) for the 1976 season with the use of a Gompertz curve. With larval lengths corrected for nettreatment and preservation-treatment, the fitted equation is

$$
L=32.2 \exp [-1.495 \exp (-0.0258 x)]
$$

where $L$ is standard length of live larvae $(\mathrm{mm})$, and $x$ is age of larvae from hatching (days). The duration of each $1-\mathrm{mm}$ length class was estimated, and a production estimate was calculated by dividing mean abundance of each class $\left(A_{L}\right)$ by its duration in days. The age-specific mortality rate was then estimated for each season by the exponential regression of durationcorrected abundance on mean age (days) of the size 
class, in the same manner previously described for the length-specific mortality rates.

\section{Potential egg production}

Comparison of potential egg production derived from larval data with an independent estimate from virtual population analysis (VPA) of spawning stock size can be instructive. In theory, if there are no large errors in the estimates of egg production, betweenyear comparison of the ratios (VPA/larvae) would reflect the consistency and magnitude of egg and early larval mortality. Alternatively, if there are no large errors in the VPA-derived estimates, comparison with the larval estimates would provide some measure of the reliability of the data from the larval surveys, at least for an annual index of spawning stock size and a gross measure of mortality in the egg and early larval stages combined.

Anthony and Waring (MS 1980) estimated egg production on Georges Bank from VPA estimates of the size of the herring stock on 1 October in each year and the available data on maturity and fecundity. They estimated that an average of $57 \%$ of age 3 herring were mature during $1967-70$ and that $93 \%$ of age 3 and all of age 4 herring were mature after 1970 . For the period of this study (1971-78), they assumed a 1:1 sex ratio and recruitment to the spawning grounds of $45 \%$ of age 3 and $78 \%$ of age 4 . A variable fecundity-length relationship, based on a density-dependent (inverse) relationship between population abundance and fecundity, was used as the basis for the VPA-derived egg production estimates in this paper. Because there are no variance estimates for the VPA population numbers or the population composition, it is not possible to place confidence limits about the VPA-based egg production estimates.

The estimates of egg production from the larval data are based on the assumption that the number of eggs is equivalent to the initial estimate of larval abundance at hatching size. This procedure ignores possible egg mortality and it may also underestimate early larval mortality.

\section{Results}

\section{Larval abundance and dispersal}

Survey coverage of the Georges Bank-Nantucket Shoals area, where major concentrations of larval herring were located, was virtually complete for the autumn seasons of 1971-72 and for the autumn-winter seasons of 1973-78 (Table 1). Atlantic herring, which have demersal eggs, typically spawn on gravelly or red algal substrate at depths of $40 \mathrm{~m}$ or less where the water is characterized by strong mixing processes

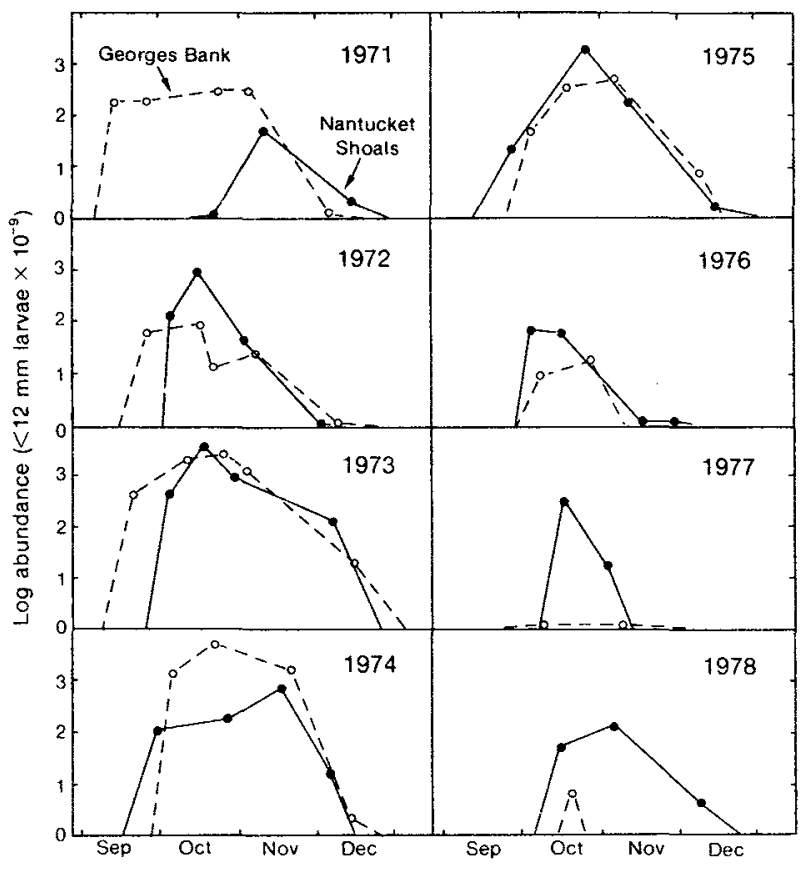

Fig. 2. Trends in seasonal abundance of larval herring ( $<12 \mathrm{~mm} \mathrm{SL})$ for the Georges Bank and Nantucket Shoals spawning grounds, $1971-78$

(Drapeau, 1973; Cooper et al., MS 1975). Hatching of larvae was observed on the Jeffreys Ledge egg beds to occur 8-9 days after spawning at a temperature of about $10^{\circ} \mathrm{C}$, and the newly-hatched larvae remained within or close to the spawning beds for 1-3 days after hatching (Caddy and Iles, 1973; Cooper et al., MS 1975). It is possible, therefore, that newly-hatched larvae $(<8 \mathrm{~mm} \mathrm{SL})$ were undersampled due to their concentration below the maximum depth of sampling or in areas which were missed because of the spacing between stations. In the present study, a station-bystation comparison of small larvae $(<10 \mathrm{~mm})$ in the $0.505-\mathrm{mm}$ and $0.333-\mathrm{mm}$ mesh samples from 13 surveys did not indicate a significant difference in mean abundance. Also, Colton et al. (1980) did not find substantial differences in size composition of larval herring in the $0.505-\mathrm{mm}$ and $0.333-\mathrm{mm}$ mesh samples from tows at 3.5 and 1.5 knots. Therefore, extrusion through the meshes is considered not to have been significant for 8-mm and larger larvae. The size of larvae at hatching is about $7-8 \mathrm{~mm}$.

The initial abundance estimates of recentlyhatched larvae $(<12 \mathrm{~mm})$ were plotted against the survey middates in each season to represent "spawning" curves for the Georges Bank and Nantucket Shoals areas (Fig. 2). For each season, the abundance indices almost invariably show a systematic progression from low to high to low numbers during the SeptemberDecember period which is consistent with concentrated spawning during a relatively short period of 
TABLE 2. Estimated initial abundance of larvae $(<12 \mathrm{~mm} \mathrm{SL})$ and hatching time for herring on the Georges Bank and Nantucket Shoals spawning grounds, 1971-78.

\begin{tabular}{|c|c|c|c|c|c|c|}
\hline \multirow[b]{2}{*}{ Season } & \multirow[b]{2}{*}{ Spawning area } & \multicolumn{2}{|c|}{ Larval abundance } & \multicolumn{3}{|c|}{ Estimated hatching period } \\
\hline & & $\left(10^{12}\right)$ & $\%$ & Dates & Middate & No. days \\
\hline \multirow[t]{2}{*}{1971} & Georges Bank & 20.9 & 93.4 & 08 Sep-24 Dec & 12 Oct & 108 \\
\hline & Nantucket Shoals & 1.5 & 6.6 & 13 Oct-01 Jan & 12 Nov & 81 \\
\hline \multirow[t]{2}{*}{1972} & Georges Bank & 3.3 & 19.6 & $16 \mathrm{Sep}-24 \mathrm{Dec}$ & 13 Oct & 100 \\
\hline & Nantucket Shoals & 13.4 & 80.4 & 30 Sep-15 Dec & 14 Oct & 77 \\
\hline \multirow[t]{2}{*}{1973} & Georges Bank & 117.9 & 59.0 & 10 Sep-04 Jan & 23 Oct & 117 \\
\hline & Nantucket Shoals & 81.9 & 41.0 & 25 Sep-26 Dec & $20 \mathrm{Oct}$ & 93 \\
\hline \multirow[t]{2}{*}{1974} & Georges Bank & 180.0 & 88.6 & 29 Sep-25 Dec & 26 Oct & 88 \\
\hline & Nantucket Shoals & 23.2 & 11.4 & 17 Sep-16 Dec & $09 \mathrm{Nov}$ & 91 \\
\hline \multirow[t]{2}{*}{1975} & Georges Bank & 16.9 & 27.0 & 28 Sep-19 Dec & 29 Oct & 83 \\
\hline & Nantucket Shoals & 45.6 & 73.0 & 14 Sep-01 Jan & $28 \mathrm{Oct}$ & 110 \\
\hline \multirow[t]{2}{*}{1976} & Georges Bank & 0.6 & 20.4 & 30 Sep-01 Nov & 22 Oct & 32 \\
\hline & Nantucket Shoals & 2.2 & 79.6 & $29 \mathrm{Sep}-07 \mathrm{Dec}$ & $11 \mathrm{Oct}$ & 70 \\
\hline \multirow[t]{2}{*}{1977} & Georges Bank & 0.02 & 0.3 & $24 \mathrm{Sep}-28 \mathrm{Nov}$ & $31 \mathrm{Oct}$ & 66 \\
\hline & Nantucket Shoais & 5.6 & 99.7 & 09 Oct- 13 Nov & 19 Oct & 36 \\
\hline \multirow[t]{2}{*}{1978} & Georges Bank & 0.1 & 1.6 & 16 Oct-26 Oct & $21 \mathrm{Oct}$ & 11 \\
\hline & Nantucket Shoals & 4.5 & 98.4 & $06 \mathrm{Oct}-26 \mathrm{Dec}$ & $02 \mathrm{Nov}$ & 82 \\
\hline
\end{tabular}

time. A spawning curve for the Georges Bank-Nantucket Shoals time series approximates a lognormal distribution with weighted middate about the end of October or early November.

Estimates of initial larval abundance and the timing and duration of the spawning (hatching) seasons on Georges Bank and Nantucket Shoals for 1971-78 are given in Table 2. Prior to the collapse of the herring stock, spawning typically occurred later on Nantucket Shoals than on Georges Bank. The northeastern part of Georges Bank was a major spawning area where newly-hatched larvae appeared in early to midSeptember and attained maximum abundance in midto late October. On Nantucket Shoals, hatching typically began in late September-early October and peak larval abundance occurred in late October-early November. The length of the spawning season contracted after 1975, particularly so for the Georges Bank area.

The initial production of larvae $(<12 \mathrm{~mm})$ in the combined Georges Bank-Nantucket Shoals area was quite high $\left(200 \times 10^{12}\right)$ in 1973 and 1974 , intermediate $\left(16-63 \times 10^{12}\right)$ in 1971,1972 and 1975 , and low $(2-5 \times$ $10^{12}$ ) in 1976, 1977 and 1978 (Table 2). The lowest estimate in the time series (1976 season) coincided with the collapse of the herring fishery on northeastern Georges Bank and a shift of the remaining spawning population to northwestern Georges Bank and Nantucket Shoals (Anthony and Waring, 1980). More than $80 \%$ of the larval population occurred on Nantucket Shoals in 1976 and thereafter. Prior to 1976 , most of the spawning occurred on Georges Bank in 1971, 1973 and 1974 and on Nantucket Shoals in 1972 and 1975.
Spawning in the two areas was closest to being equal in 1973 when the strong 1970 year-class matured as 3year-olds. Larval production in 1971 is probably underestimated, because the third survey of the season (9-25 October) did not sample seveal stations on the historic egg-beds of Nantucket Shoals.

Contoured distributions of different uncorrected size-groups of larvae from four surveys during September-December 1974 (Fig. 3) show a fairly typical sequence of dispersion from the spawning grounds on Georges Bank and Nantucket Shoals. With the spawning areas designated by the main concentrations of $<10 \mathrm{~mm}$ larvae and since larval herring grow in length about $5 \mathrm{~mm}$ per month, the distribution of successive size groups of larvae $(10-15,15-20$, and $20-25 \mathrm{~mm}$ ) at approximately monthly intervals generally reflect the dispersal pattern. Peculiarities in the origin and dispersal of larvae for each season will not be discussed in detail here but some important generalizations will be noted. Larvae which originate from the Georges Bank and Nantucket Shoals spawning areas disperse rapidly over the shoal areas and reach the maximum extent of their distributions by late November or early December, following which the populations decline rapidly. During the late autumn and winter months, a mean southerly flow of surface water is evident on Georges Bank with a westerly component across the Great South Channel (Bumpus, 1976; Butman et al., 1982; Limeburner and Beardsley, 1982). Larvae from the spawning area on northeastern Georges Bank typically disperse to the southwest across the bank at 2-15 $\mathrm{km} /$ day and intermix with larvae from the Nantucket Shoals spawning area. Larger larvae are sometimes found off the northern edge of the bank in the southern 

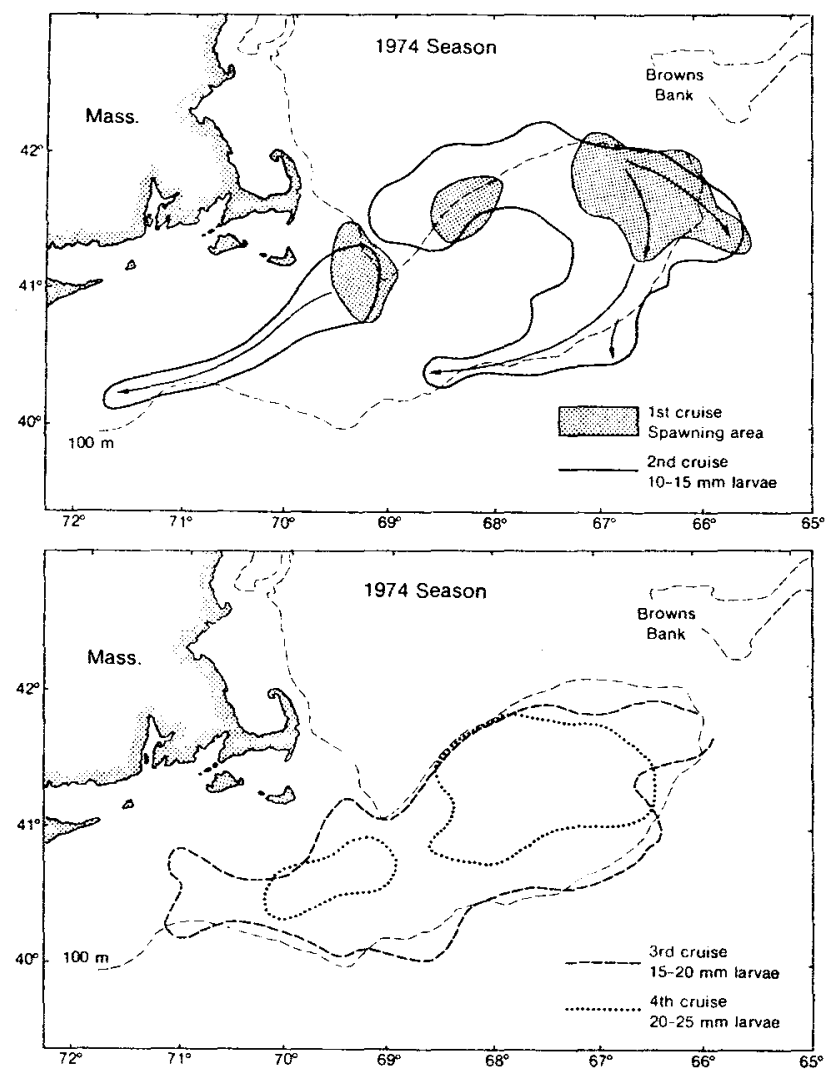

Fig. 3. Example of initial distribution (shaded) and subsequent dispersion of a cohort of larval herring from the Georges Bank and Nantucket Shoals spawning grounds over four surveys from October to December 1984. (Contours based on larval concentrations greater than $1 / \mathrm{m}^{2}$ for the first three cruises and greater than $0.5 / \mathrm{m}^{2}$ for the fourth cruise.)

Gulf of Maine, in lobes extending off the northeast peak, and in slope water south of the bank, but generally the bulk of the larval population is found within the $100-\mathrm{m}$ isobath throughout the season. There is $\mathrm{min}-$ imal evidence of any cross-transport of larvae between Georges Bank and Browns Bank on the Scotian Shelf or between Nantucket Shoals and coastal western Gulf of Maine, at least during the first 6 months of their life.

The shallow parts $(<25 \mathrm{~m})$ of Nantucket Shoals, which may be important nursery grounds for larvae and juveniles, were not sampled adequately in any year. Larvae produced in near-shore waters apparently migra te into the estuaries and embayments during the autumn and remain there throughout the winter (Graham and Davis, 1971; Graham et al., 1972). Also, at times, survey coverage did not extend far enough off the southern edge of Georges Bank or far enough westward in southern New England waters to encompass the most extreme reaches of the larval populations through the course of their early life. The extent of the underestimation of larval abundance due to incomplete survey coverage is not known, but it should not materially affect the derived estimates of mortality.

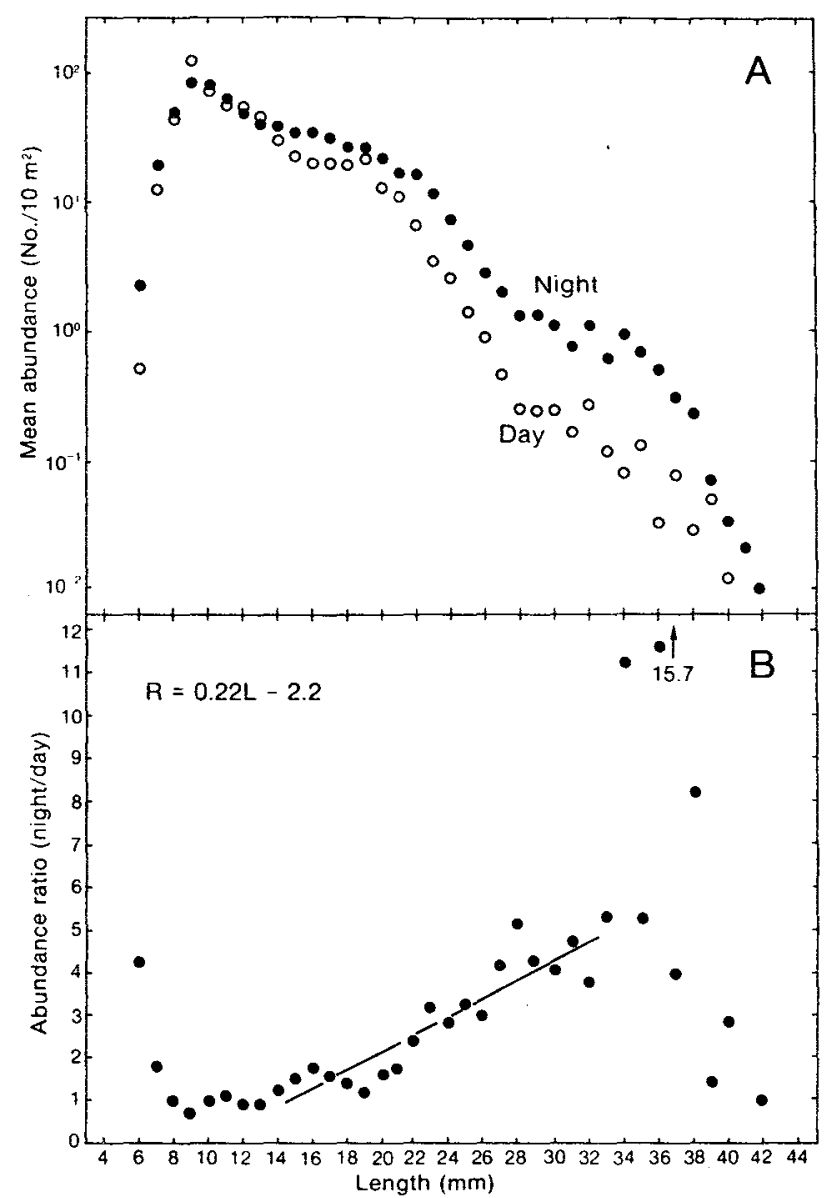

Fig. 4. Mean abundance of night and day catches of larval herring by size-groups (A) and the corresponding night/day abundance ratios (B), based on data from 35 surveys of Georges BankNantucket Shoals region during the 1971-77 spawning seasons. (Regression line was fitted to ratios for $15-32 \mathrm{~mm}$ groups.)

\section{Seasonal production and mortality}

Avoidance of the net by larger larvae is readily evident in the plot of mean abundance of larval herring by $1-\mathrm{mm}$ length classes from night and day samples combined for all surveys (Fig. 4A). Larval abundance was highest at $8-9 \mathrm{~mm}$ (recently-hatched) and declined exponentially with increasing size of larvae so that very few larvae larger than $26 \mathrm{~mm}$ were caught. Although the overall mean abundance of larvae from the day and night samples did not differ significantly, there was a definite trend toward more larvae being caught at night than in the daytime, especially sizes larger than $14 \mathrm{~mm}$. The average percentage of tows during the night in all seasons was $55.3 \%$. Ratios of night to day abundance (Fig. 4B) are near unity for 8-14 $\mathrm{mm}$ larvae, increase approximately linearly to 5 at $32 \mathrm{~mm}$, and then exhibit extreme variability with evidence of a decline for larvae larger than $38 \mathrm{~mm}$. These ratios indicate that visual avoidance of the net by larvae began at about $14 \mathrm{~mm}$, increased at a fairly constant 
TABLE 3. Average seasonal instantaneous mortality rates for larval herring in the Georges Bank-Nantucket Shoals region, 1971-78. (Length-specific mortality estimated for the 8-32 $\mathrm{mm}$ length classes and age-specific mortality for the period of 4-181 days from hatching: abundance at hatching size $(7.8 \mathrm{~mm} \mathrm{SL})$ estimated from exponential regression of abundance on length.)

\begin{tabular}{|c|c|c|c|c|c|c|c|c|}
\hline \multirow[b]{2}{*}{ Season } & \multicolumn{3}{|c|}{ Length-specific mortality } & \multirow[b]{2}{*}{$\begin{array}{c}\text { Abundance } \\
\text { at hatching } \\
\qquad\left(10^{12}\right)\end{array}$} & \multicolumn{4}{|c|}{ Age-specific mortality } \\
\hline & $\begin{array}{l}\text { Instantaneous } \\
\text { coefficient } \\
(-Z)\end{array}$ & $\begin{array}{l}\text { Standard } \\
\text { error } \\
\text { (SE) }\end{array}$ & $\begin{array}{l}\text { Coefficient of } \\
\text { determination } \\
\qquad\left(r^{2}\right)\end{array}$ & & $\begin{array}{c}\text { Instantaneous } \\
\text { coefficient } \\
(-Z)\end{array}$ & $\begin{array}{l}\text { Standard } \\
\text { error } \\
\text { (SE) }\end{array}$ & $\begin{array}{l}\text { Coefficient of } \\
\text { determination } \\
\qquad\left(r^{2}\right)\end{array}$ & $\begin{array}{l}\text { Percent } \\
\text { daily } \\
\text { rate }\end{array}$ \\
\hline 1971 & 0.238 & 0.028 & 0.767 & 41.6 & 0.062 & 0.003 & 0.951 & 6.0 \\
\hline 1972 & 0.233 & 0.028 & 0.765 & 21.6 & 0.056 & 0.005 & 0.854 & 5.5 \\
\hline 1973 & 0.182 & 0.023 & 0.741 & 116.7 & 0.049 & 0.003 & 0.911 & 4.8 \\
\hline 1974 & 0.191 & 0.010 & 0.948 & 77.9 & 0.047 & 0.002 & 0.954 & 4.6 \\
\hline 1975 & 0.161 & 0.017 & 0.804 & 20.7 & 0.039 & 0.004 & 0.836 & 3.8 \\
\hline 1976 & 0.126 & 0.017 & 0.724 & 0.9 & 0.036 & 0.004 & 0.811 & 3.5 \\
\hline 1977 & 0.197 & 0.024 & 0.749 & 4.2 & 0.049 & 0.004 & 0.856 & 4.8 \\
\hline 1978 & 0.270 & 0.031 & 0.821 & 2.5 & 0.074 & 0.008 & 0.836 & 7.1 \\
\hline
\end{tabular}

rate to a size of $32 \mathrm{~mm}$, and varied so much for the larger larvae that the abundance estimates could not be corrected easily. The possible underestimation of abundance for larvae larger than $14 \mathrm{~mm}$ has the effect of increasing the estimates of seasonal mortality rates compared to what they would have been if net avoidance had not occurred. One also must bear in mind that there was no February survey in the 1971 or 1972 season, and thus the overall abundances of the largest size-groups of larvae (sizes normally caught in February) may be underestimated.

Length-specific mortality coefficients $(Z)$ for the 1971-78 seasons ranged from a low of 0.126 per $\mathrm{mm} \mathrm{SL}$ in 1976 to a high of 0.270 per $\mathrm{mm}$ in 1978 (Table 3). The coefficients for the 1971-75 and 1977 seasons (0.161-0.238) were not significantly different by an analysis of covariance, the common slope of the regression line being 0.200 with $95 \%$ confidence inter$\mathrm{val}$ of $0.160-0.240$. The coefficient for the 1976 season was significantly lower $(P<0.05)$ and that for the 1978 season was significantly higher $(P<0.01)$ than the common value for the other five seasons. Thus, based on the average seasonal decline in abundance, it appears that the system was uniform during the 1971-75 spawning seasons but became unstable thereafter, coincident with the collapse of the Georges Bank herring stock in 1976.

The age-specific mortality coefficients followed the same trend as the length-specific mortality rates over the 1971-78 seasons, with a low value of 0.036 per day in 1975 and a high value of 0.074 in 1978 . However, an evaluation of the significance in differences was not made in this case because of deficiencies in methodology related to the growth model. First, the growth model which was developed from data for the 1976 season was applied to the data for all seasons, because age data were lacking for the other seasons and the polymodal length frequencies did not permit more quantitative estimates of growth. Also, variation in length-at-age may have occurred during the 1971-78 seasons due to differences in the temperature regime (Grimm, 1983) and prey field (Cohen and Lough, 1983). Second, it is difficult to derive an accurate age for older larvae from their lengths alone because of slower growth, noticeably after 90 days of wintering, which produces a wide range of larval ages over a small size range (Lough et al., 1982). Ideally, representative age distributions should be determined independently for each survey. At best, the age-specific mortality during the 1971-78 seasons may be characterized as having a mean rate of about $5 \%$ per day with a range of $3-7 \%$ per day during the first 6 months of life.

Another estimate of larval production at hatching size can be made for each season from the length specific exponential regressions (Table 3). Again, these estimates should be viewed as indices because mortality can be highly variable during the season. The estimates of initial larval abundance for the 1971-78 seasons by this method are comparable within factors of 2-3 with those that were derived by summing the numbers of larvae in length classes $<12 \mathrm{~mm}$ (Table 2 ), the relative ranking of seasons being the same by both methods. Similar initial production indices were estimated by Schnack (MS 1975) from the 0.505-mm mesh samples for the 1971-74 seasons. Combination of the range estimates of initial larval abundance by the two methods (Tables 2 and 3 ) show that production was highest $\left(78-203 \times 10^{12}\right)$ in the 1973 and 1974 seasons, intermediate $\left(17-63 \times 10^{12}\right)$ in 1971, 1972 and 1975, quite low (3-6 $\left.\times 10^{12}\right)$ in 1977 and 1978, and lowest (1-3 $\left.\times 10^{12}\right)$ in 1976 .

\section{Production estimates from VPA and larval surveys}

Estimates of egg production from the VPA age 3+ population and the estimates of larval abundance at hatching (Table 3) are compared in Fig. 5. The comparison is possible only for 1971-76 because there was no herring fishery on Georges Bank after 1976. The estimates of initial larval abundance in 1973 and 1974 are much larger than the VPA estimates of egg production, 


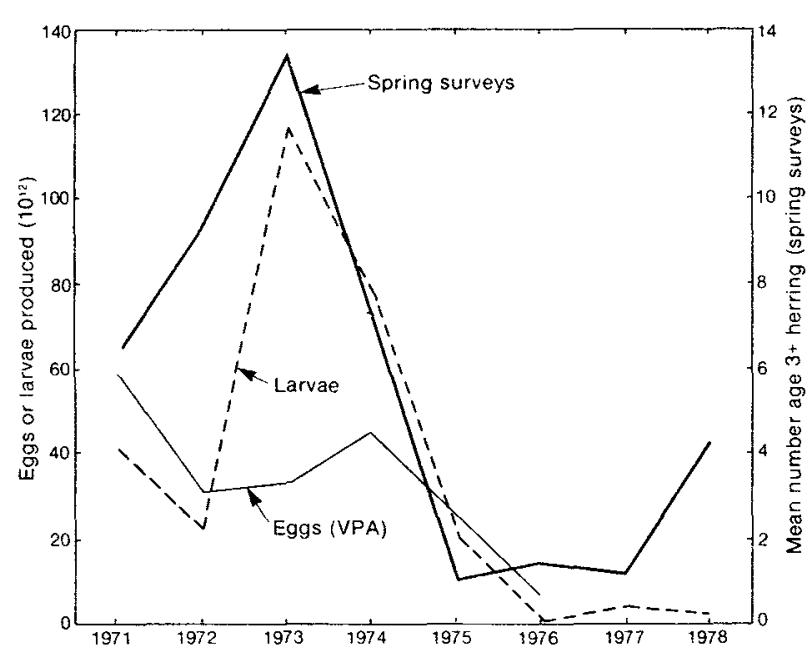

Fig. 5. Trends in larval production of herring in the Georges BankNantucket Shoals region during the 1971-78 spawning seasons, in relation to VPA-based estimates of egg production of age $3+$ herring, and to the abundance index of age $3+$ herring from spring groundfish surveys of the region from Georges Bank to Cape Hatteras.

but, in the other years $(1971,1972,1975$ and 1976), the VPA estimates were larger than the larval estimates, particularly so for the 7-fold difference in 1976. Suspected bias in the larval estimates for 1971 and 1976 is thought to be due to factors which may have led to underestimates of larval production. In 1971, sampling coverage of Nantucket Shoals was not as complete as in other years and therefore larval abundance may have been underestimated. In 1976, the underestimate of larval production may have been more serious, because there is evidence of an unusual degree of advective loss of ichthyoplankton from Georges Bank (Lough et al., 1981; Boiz and Lough, 1984). With respect to sampling error associated with the estimates of larval abundance, coefficients of variation (CV) were around $35 \%$, based on haul-to-haul variability in the larval surveys. It seems more likely that the VPA estimates of egg production are low, because there is no reason to suspect further bias in the larval estimates than the negative systematic bias noted above. Furthermore, the larval data correspond well with other information on the herring population.

A fishery-independent index of herring spawning stock size was derived from the spring (March) stratified-random bottom-trawl surveys of the Georges Bank, southern New England and Mid-Atlantic Bight areas (Sissenwine and Waring, MS 1980). The mean numbers of herring (age $3^{+}$) per tow from the 1971-78 surveys (Fig. 5) represent indices of abundance of the spawning stock. The sampling errors associated with the trawl-survey indices ( $\mathrm{CV}=43 \%$, Anthony et al., MS 1975) are roughly the same order of magnitude as those associated with the indices of larval abundance, and, therefore, one would not expect a very high correlation between them. Nevertheless, both the larval and trawl-survey indices of abundance show general agreement, and, in particular, they both show a large increase to peak abundance in 1973, consistent with the recruitment of the 1970 year-class which was known to be a strong one (Anthony and Waring, 1980). In contrast, the VPA estimates of egg production from the stock in 1973 was virtually the same as that in 1972 , and this seems untenable in view of the confirmed strength of the 1970 year-class (ICNAF, 1974). It is also untenable to attribute such an apparent shortfall in egg production in 1973 to a sudden reduction in fecundity, maturation rate or recruitment rate, because the only process that might cause such a large bias in the VPAbased egg production estimate would be a major shift in concentration of fishing effort over the spawning season in relation to the pattern of gonad ripening and the removal of widely varying proportions of the spawning stock prior to egg deposition. This does not appear to have happened on Georges Bank. From the proportions of the estimated spawning stock that were removed by fishing during September-November periods of 1971-76 (Fig. 6), it is evident that catches were higher in September and October of 1972 and 1975 $(20-50 \%)$ than in the same months of other years $(<20 \%)$. With respect to the seasonal pattern of gonad ripening, virtually all herring were ripe in September 1971 whereas at least $50 \%$ were still in prespawning condition in September of all other years (Anthony and Waring, MS 1980). Taking both of these factors into account, the rate of removal of potential spawners would appear to have been highest in 1972 and 1975 , and these were the years when the VPA-based estimates of egg production were higher than the survey estimates of initial larval production. In contrast, the removal of potential spawners appeared to have been lowest in 1973 and 1974 when the VPA-based estimates of egg production were considerably lower than the estimates of initial larval production.

\section{Discussion}

Studies on the abundance of early life-history stages of fish from egg and larval surveys have been motivated primarily with the aim of predicting the size of recruiting year-classes and/or estimating the size of spawning stocks (Saville and Schnack, 1981). In the case of the ICNAF larval herring surveys, however, the main focus was to identify ecological relationships during the period from post-hatching to early metamorphosis. The estimation of larval mortality rates and causes for their differences remain a principal concern for fishery biologists in resolving the fish stock and recruitment problem, despite the inherent sampling problems and the long-term commitment required for these studies (Hunter, 1976). In this paper, data from surveys during the 1971-78 spawning seasons of Atlantic herring were examined for patterns and significant changes in the timing and distribution of spawning, initial production of larvae, and average larval 


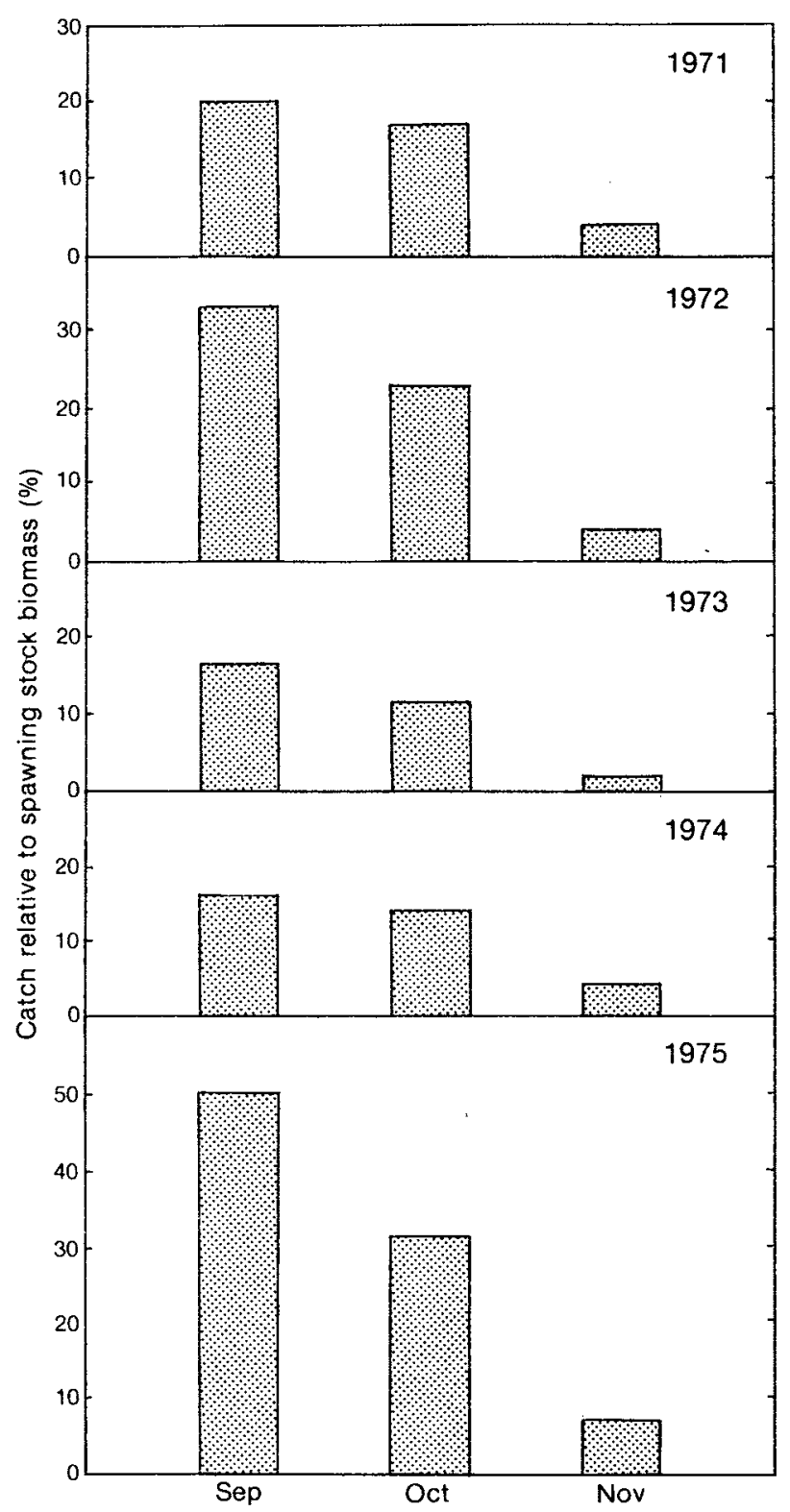

Fig. 6. Trends in commercial catch of herring relative to biomass of the spawning stock (age $3^{+}$) in the Georges Bank-southern New England region for the 1971-75 spawning seasons.

mortality on Georges Bank and Nantucket Shoals. The survey cannot provide absolute measures of spawning stock size because there are no reliable estimates of mortality of the demersal eggs and the larvae at the time of hatching. Therefore, the production estimates have been considered as indices of abundance, in which the trends can be compared with those in other independent measures of stock size. Similarly, the estimated mortality rates do not necessarily infer that mortality was constant throughout a season, but they should be viewed as a baseline for noting the occurrence of significant deviations.

The estimates of initial larval production by the various methods show the same relative ranking by years and spawning areas. The highest production of larvae occurred in 1973 and 1974 as a result of the strong 1970 year-class. Production before (1971 and 1972) and after (1975) the peak seasons was about an order of magnitude lower than in 1973 and 1974. In 1976 and thereafter, production was about two orders of magnitude lower, signifying the demise of the spawning stock on Georges Bank. This demise is reflected by contraction of the spawning period, a shift in virtually all spawning activity to the Nantucket Shoals area in 1976, and a significant change in the mortality pattern over the study period.

Mortality of eggs on the spawning beds is believed to be due primarily to predation which may vary significantly. Although herring eggs may be deposited in layers up to $5 \mathrm{~cm}$ thick, observations in the Gulf of Maine and Georges Bank areas indicated that mortality of eggs from spawning to hatching may be less than $1 \%$, excluding predation (Pankratov and Sigajev, 1973; Cooper et al., MS 1975). Survival is believed to be greater for eggs which are deposited in thin layers, such as on algal-covered substrate, than for those in multilayered beds. In coastal areas, red algae provide a suitable substrate in depths less than $40 \mathrm{~m}$ (McKenzie, 1964; Cooper et al., MS 1975). However, predation on herring eggs by various species of fish and invertebrates was estimated by Caddy and Iles (1973) to have been $8 \%$ within 1-2 days after egg deposition on Georges Bank in 1970. Hatching occurs about 8-9 days after spawning (at $10^{\circ} \mathrm{C}$ ). Hence, predation commensurate with the 1970 observations would account for the loss of $30-70 \%$ of the total number of eggs deposited, or $4-14 \%$ per day. If egg-bed mortality is a significant factor, due to smothering of eggs in high-density masses or to heavy predation, it is more likely to have occurred in the late 1960's when the stocks of herring and principal groundfish species were larger (Clark and Brown, 1977; Grosslein et al., 1980). There is no information for this region on trends in abundance of invertebrates which prey on herring eggs. If densitydependent mortality is hypothesized, one would expect years of unusually high or low larval abundance to have correspondingly high or low ratios of VPAbased to larval-survey production estimates. In any case, high egg mortality due to predation at any time in the 1970's was unlikely, because the numbers of known predators of herring eggs, especially cod and haddock, were much lower during this period than in earlier years.

The pattern of differences between the VPA-based and larval-survey production estimates is opposite what would be expected and it is unlikely that the above-noted sources of bias were responsible for the low VPA-based estimates of egg production for 1973 and 1974. A more probable explanation for these low estimates is unreported catch, at least in 1973 and 1974 , which would result in underestimates of stock 
size and hence egg production. In the early 1970's, there was a great deal of concern about the declining herring stock on Georges Bank, and pressure for reduction in fishing mortality, through imposition of national catch quotas, was building rapidly within ICNAF (Anthony and Waring, 1980). Even though the approved quotas were much higher than those that were recommended by ICNAF's Standing Committee on Research and Statistics, there may still have been an incentive for some countries to under-report catches. Although this cannot be confirmed directly, it does offer a plausible explanation for the observed discrepancies and it may help to explain the sudden disappearance of herring on Georges Bank at a time when the spawning stock was assessed to be 200,000 tons or more (Anthony and Waring, 1980, table 16). These authors suggested that physical interruption of spawning activity by too many fishing vessels may have contributed to the failure in recruitment after 1970 , but that suggestion is not supported by the larval-survey data which indicated significant egg production in 1973 and 1974, as would be expected with recruitment of the strong 1970 year-class.

The average mortality rates of $3-7 \%$ per day, as estimated for larval herring in the Georges Bank-Nantucket Shoals areas, are in agreement with the generalized mortality curve for other species of fish with high fecundities. The exponential loss in numbers between hatching and recruitment to the fishery is typically 4-7 orders of magnitude (Cushing, 1974). Mortality rates of larval herring from various field, enclosure and laboratory studies are summarized in Table 4 . In studies where adequate sampling or rearing of yolksac larvae appears to have been made, some have observed a constant mortality rate throughout the early larval phase consistent with that for older larvae ( $\varnothing$ iestad and Moksness, 1981; Henderson et al., 1984). However, most studies show higher-than-average mortality (8-35\%/day) during the yolksac stage in the first week or two after hatching (Saville, 1965; Blaxter, 1968; Dragesund and Nakken, 1973; Graham and Chenoweth, 1973; Gamble et al., 1981). These studies indicate that, in many cases, high mortality occurs at the end of yolksac resorption when the first feeding larvae are particularly vulnerable to starvation (Blaxter and Ehrlich, 1974, May, 1974). The magnitude of this early mortality cannot be estimated from the larval herring data used in this paper, because the newly-hatched yolksac larvae were observed by divers to stay within the egg bed or within a meter of the bottom for $1-3$ days after hatching (Caddy and Iles, 1973; Cooper et al., MS 1975). The gear used during the ICNAF larval herring surveys only sampled the water column from the surface to $5 \mathrm{~m}$ off the bottom and the survey design was inadequate to measure the abundance of larvae that were less than a week old. Mortality rates of older larvae during the winter period in the Gulf of MaineGeorges Bank area have been estimated by Lough (MS 1976a), Graham and Davis (1981) and Graham (1982) to be lower $(1-6 \% /$ day) than the average for the autumn-winter period, but these rates may be underestimates because of net avoidance.

In natural populations of larvae, mortality probably varies around some average rate which could be measured if a suitable sampling program was instituted. From a review of larval herring studies, it appears that successive stages of the larval period should be examined more closely, because survival, as well as the causes of mortality, may be different during each of these stages. However, the precise estimation of larval mortality during short periods $(<2$ weeks), is not possible with large-scale surveys. Finer-scale sampling is necessary to determine the precise timing of the different larval stages and possible changes in mortality rate within these stages. Possible mortality mechanisms that cause these changes should be examined in order to sort out the relative importance of each mechanism.

Despite the limitations in precision of data from large-scale research vessel surveys, it is important to note that they are extremely useful for following major trends in spawning stocks. Although sampling errors are large, the data at least provide indices which do not have some of the biases that are inherent in stock assessments based on fishery statistics. The ICNAF larval herring surveys during 1971-78 were successful, not only as an experiment involving scientific cooperation among several nations, but also in providing a valuable fishery-independent index of abundance for a fish stock of international importance.

\section{Summary}

Larval herring catches during 39 ICNAFcoordinated surveys of the Georges Bank-Nantucket Shoals area in the 1971-78 spawning seasons were used to estimate the abundance and mortality of larvae during the first 6 months of life for comparison with other data on the spawning stock.

Spawning occurred in shoal water on the historic egg-bed sites of northern Georges Bank and Nantucket Shoals from September to December, being dominant in one area or the other during the time series with peaks in October-early November of each year. In recent years, the onset of spawning was delayed and the length of the spawning season shortened, particulariy after 1975, coincident with the collapse of the herring fishery on northeastern Georges Bank and a shift of the remaining spawning population to northwestern Georges Bank and Nantucket Shoals.

Seasonal estimates of larval abundance were made from day-night adjusted catches by the expanded day and area method, whereby the mean 
TABLE 4. Mortality rates of Atlantic herring larvae from field, enclosure and laboratory studies.

\begin{tabular}{|c|c|c|c|c|}
\hline $\begin{array}{l}\text { Study area or } \\
\text { containment }\end{array}$ & $\begin{array}{l}\text { Length } \\
(\mathrm{mm})\end{array}$ & $\begin{array}{c}\text { Mortality } \\
(\% / \text { day })\end{array}$ & Comments & Source \\
\hline \multicolumn{5}{|c|}{ Field studies } \\
\hline \multirow[t]{2}{*}{$\begin{array}{l}\text { Georges Bank and } \\
\text { Nantucket Shoals }\end{array}$} & $8-32$ & $3-7$ & $\begin{array}{l}\text { Autumn-winter, } 6 \text {-month period, } \\
4-181 \text { days from hatching }\end{array}$ & This study \\
\hline & $14-31$ & $1-6$ & $\begin{array}{l}\text { Mid-December to mid-February, } \\
\text { 2-month period }\end{array}$ & Lough (MS 1976a) \\
\hline Georges Bank & $\begin{array}{c}4-9 \\
\text { yolksac }\end{array}$ & 29 & $75 \%$ over 4 -day sampling period & Graham and Chenoweth (1973) \\
\hline $\begin{array}{l}\text { Sheepscot River } \\
\text { Estuary, W. Maine }\end{array}$ & $\sim 20-34$ & $<1-6$ & $\begin{array}{l}33-99 \% \text { over } 3 \text {-month period, } \\
\text { mid-December to mid-March }\end{array}$ & $\begin{array}{l}\text { Graham (1982), Graham and } \\
\text { Davis (1981) }\end{array}$ \\
\hline Central North Sea & $4-21$ & $4-6$ & $\begin{array}{l}79-82 \% \text { over } 5 \text {-week period, } \\
\text { September-October }\end{array}$ & Wood and Burd (MS 1976) \\
\hline $\begin{array}{l}\text { River Blackwater } \\
\text { Estuary, U.K. }\end{array}$ & $6-25$ & $6-7$ & 35-50 day period, April-June & Henderson et al. (1984) \\
\hline $\begin{array}{l}\text { Clyde Estuary, } \\
\text { W. Scotland }\end{array}$ & Hatch-? & $10-35$ & $\begin{array}{l}\text { Highest loss within } 1-2 \text { weeks } \\
\text { after hatching, March }\end{array}$ & Saville (1965) \\
\hline Møre, Norway & $\begin{array}{r}10-12 \\
\text { yolksac }\end{array}$ & 27 & $\begin{array}{l}94 \% \text { over 9-day period, early } \\
\text { April }\end{array}$ & Dragesund and Nakken (1971) \\
\hline Norwegian W. Coast & $9-13$ & $8-19$ & $70-95 \%$ over 2 weeks in April & Dragesund and Nakken (1972) \\
\hline $\begin{array}{l}\text { Lindaaspollene, } \\
\text { Western Norway }\end{array}$ & $6-28$ & $8-16$ & $2 \frac{1}{2}$-month period, April-June & Johannessen (1983) \\
\hline \multicolumn{5}{|c|}{ Enclosure studies } \\
\hline \multirow[t]{2}{*}{ Basin $\left(4,440 \mathrm{~m}^{3}\right)$} & $9-21$ & 4 & $6 \%$ over 18 -day period & $\varnothing$ iestad and Moksness (1981) \\
\hline & $9-?$ & 3 & $30 \%$ over 113 -day period & \\
\hline \multirow[t]{2}{*}{ Plastic bag $\left(1.8 \mathrm{~m}^{3}\right)$} & $9-15$ & $3-8$ & $53-84 \%$ over 22 -day period & $\varnothing$ iestad and Moksness (1981) \\
\hline & $9-11$ & $3-8$ & $32-62 \%$ over 12 -day period & \\
\hline \multirow[t]{3}{*}{ Plastic bag $\left(310 \mathrm{~m}^{3}\right)$} & $6-7$ & $8-18$ & $80-90 \%$ on first day of hatch & Gamble et al. (1981) \\
\hline & $8-12$ & 8 & $9-10$ days after hatching & \\
\hline & $8-18$ & 3 & $\begin{array}{l}\text { Steady decline in } 40-50 \text { day } \\
\text { period }\end{array}$ & \\
\hline \multicolumn{5}{|c|}{ Laboratory studies } \\
\hline Tank (200 I) & $\begin{array}{c}6-8 \\
\text { yolksac }\end{array}$ & $14-18$ & $\begin{array}{l}65-75 \% \text { during yolksac stage, } \\
7 \text {-day period }\end{array}$ & Blaxter (1968) \\
\hline Tank $(301)$ & $7-9$ & 12 & $\begin{array}{l}\text { 13-day period with noticeable } \\
\text { increase to end of yolksac } \\
\text { stage, } 6 \text { days from hatching }\end{array}$ & Laurence (unpubl. data) \\
\hline
\end{tabular}

density of larvae during each survey was estimated for each 1-mm length-class over a size range of $8-32 \mathrm{~mm}$. Length-specific instantaneous mortality rates $(Z)$ were estimated for each season by the exponential regression of larval abundance on length, and estimates of initial abundance of larvae at size of hatching were derived. Mortality as a function of age was estimated by coupling the length-specific exponential regression equations with the Gompertz growth curve which described the growth in length of herring larvae over 181 days.

Indices of the initial production of larvae in the Georges Bank-Nantucket Shoals area were estimated to be quite high in 1973 and 1974 (78-203 $\times 10^{12}$ larvae) due to maturation of the strong 1970 year-class, intermediate in 1971, 1972 and $1975\left(17-63 \times 10^{12}\right)$, low in 1977 and $1978\left(3-6 \times 10^{12}\right)$ and extremely low in 1976 $\left(1-3 \times 10^{12}\right)$.

Length-specific mortality rates were not significantly different for the 1971-75 and 1977 seasons (mean $0.200 / \mathrm{mm}$, confidence limits $0.160-0.240$ ). The mortality rate for $1976(0.126 / \mathrm{mm})$ was significantly lower and for $1978(0.270 / \mathrm{mm})$ was significantly higher than the average rate for the other years. Age-specific mortality was $3-7 \%$ per day over the $1971-78$ seasons, with an average of $5 \%$ per day during the first 6 months 
of life. Mortality of the smallest larvae was probably higher than average during the first week or two after hatching, but these were not adequately sampled during the surveys. Mortality was lower than average for larger overwintering larvae.

Estimates of larval abundance from the herring surveys were compared with VPA-based estimates of egg production for the 1971-76 period. These indices were also compared with a fishery-independent index of spawning stock size (number per tow of age 3+ herring) from the spring bottom-trawl surveys of the region. After taking various factors into account it was concluded that the VPA-based estimates of egg production in 1973 and 1974 were substantially underestimated, due possibly to unreliable fishery statistics for these years, and the survey estimate of larval abundance for 1976 may be underestimated because of advective loss of larvae from Georges Bank by currents.

\section{Acknowledgements}

The ICNAF larval herring surveys represent more than a decade of intense, cooperative activity by five principal fisheries research institutes: Institut für Meereskunde, Kiel, Federal Republic of Germany; Institute Scientifique et Technique des Pêches Maritimes, St. Pierre et Miquelon, France; Sea Fisheries Institute, Gdynia, Poland; Atlantic Research Institute of Marine Fisheries and Oceanography (AtlantNIRO), Kaliningrad, USSR; Northeast Fisheries Center, Woods Hole, Massachusetts, USA. We thank the countless scientists who participated in the surveys as well as those who served on various working groups that were instrumental in planning and coordinating the cruises and the data analysis. The larval herring from the $0.505-\mathrm{mm}$ mesh samples were processed by each participating country, and those from the $0.333-\mathrm{mm}$ mesh samples were processed by the Polish Sorting Center, Morski Instytut Rybacki, Szczecin, Poland. All preliminary data processing, involving quality control and the production of standardized data summaries and station plots, was accomplished by the Biostatistical Group, Northeast Fisheries Center, Narragansett Laboratory, Narragansett, Rhode Island, USA.

\section{References}

AITCHISON, J., AND J. A. C. BROWN. 1957. The lognormal distribution. Cambridge Univ. Press, London, $176 \mathrm{p}$

ANTHONY, V. C., and G. T. WARING. 1980. The assessment and management of Georges Bank herring fishery. ICES Rapp. Proc.Verb., 177: 72-111.

MS 1980. Estimates of herring spawning stock biomass and egg production for the Georges Bank-Gulf of Maine region. NAFO SCR DOC., No. 135, Serial No. N209, 38 p.

ANTHONY, V. C., C. W. DAVIS, G. WARING, M.D. GROSSLEIN, and T
BURNS. MS 1975. Size distribution and recruitment estimates for sea herring of the Georges Bank-Gulf of Maine region, based on trawl surveys by research vessels. ICNAF Res. Doc., No. 110 Serial No. $3603,45 \mathrm{p}$.

AU. D. W. K. MS 1974. Preliminary report of ICNAF larval herring (Clupea harengus) survey in the Gulf of Maine and on Georges Bank during December 1973. ICNAF Res. Doc., No. 17, Serial No. $3163,5 \mathrm{p}$.

BALKOVOY, V. A., T. L. SIGAEV, and A. P. NAKONECHINAJA. MS 1975. The results of the survey on abundance and distribution of herring larvae on Georges Bank, 10-30 October 1974. ICNAF Res. Doc., No. 66, Serial No. 3550, 21 p.

BLAXTER, J. H. S. 1968. Rearing herring larvae to metamorphosis and beyond. J. Mar. Biol. Assoc. U.K., 48: 17-28.

BLAXTER, J. H. S., and K. F. EHRLICH. 1974. Changes in behaviour during starvation of herring and plaice larvae. In The early life history of fish, J. H. S. Blaxter (ed.), Springer-Verlag, Berlin, $p$ 575-588.

BOLZ, G. R., and R. G. LOUGH. 1984 Retention of ichthyoplankton in the Georges Bank region during the autumn-winter season, 1971-77. J. Northw. Atl. Fish. Sci., 5: 33-45.

BOYAR, H. C., R. R. MARAK, F. E. PERKINS, and R. A. CLIFFORD 1973. Seasonal distribution and growth of larval herring (Clupea harengus L.) in the Georges Bank-Gulf of Maine area from 1962 to 1970. ICES J. Cons., 35: 36-51.

BUMPUS, D. F. 1976. Review of the physical oceanography of Georges Bank. ICNAF Res. Bull., 12: 119-134.

BUTMAN, B., R. C. BEARDSLEY, B. MAGNELL, D. FRYE, J. A. VERMERSCH, R. J. SCHLITZ, R. LIMEBURNER, W. R. WRIGHT, and M. A. NOBLE. 1982. Recent observations of the mean circulation on Georges Bank. J. Phys. Oceanogr., 12: 569-591.

CADDY, J. F., and T. D. LLES. 1973. Underwater observations on herring spawning grounds on Georges Bank. ICNAFRes. Bull., 10: 131-139.

CLARK, S. H., AND B. E. BROWN. 1977. Changes in biomass of finfishes and squids from the Gulf of Maine to Cape Hatteras, 1963-74, as determined from research vessel survey data. Fish. Bull. U.S., 75: 1-21.

COHEN, E. B., M. D. GROSSLEIN, M. P. SISSENWINE, F. STEIMLE, and W. R. WRIGHT. 1982. Energy budget of Georges Bank. Can. Spec. Publ. Fish. Aquat. Sci., 59: 95-107.

COHEN, R. E., and R. G. LOUGH. 1983. Prey field of larval herring Clupea harengus on a continental shelf spawning area. Mar. Ecol. Prog. Ser., 10: 211-222.

COLTON, J. B., and R. R. BYRON. MS 1976. Summary of ichthyoplankton collected by U.S. vessels during ICNAF larval herring surveys, September 1971 to February 1975. ICNAFRes. Doc., No. 95, Serial No. 3915,33 p.

COLTON, J. B., K. A. HONEY, and R. F. TEMPLE. 1961. The effectiveness of sampling methods used to study the distribution of larval herring in the Gulf of Maine. ICES J. Cons., 26: 180-190.

COLTON, J. B., J. R. GREEN, R. R. BYRON, and J. L. FRISELLA. 1980. Bongo net retention rates as effected by towing speed and mesh size. Can. J. Fish. Aquat. Sci., 37: 606-623.

COOPER, R. A., J.R. UZMANN. R. A. CLIFFORD, and K. J.PECCI. MS 1975. Direct observations of herring (Clupea harengus harengus L.) egg beds on Jeffreys Ledge, Gulf of Maine, in 1974. ICNAFRes. Doc., No. 93, Serial No. 3573, 6 p.

CUSHING, D. H. 1974. The possible density-dependence of larval mortality and adult mortality in fishes. In The early life history of fish, J. H. S. Blaxter (ed.), Springer-Verlag, Berlin, p. 103-111.

DAS, N. 1968. Spawning, distribution, survival, and growth of tarval herring (Clupea harengus L.) in relation to hydrographic conditions in the Bay of Fundy. Fish. Res. Board Can. Tech. Rep., 88 $129 \mathrm{p}$.

1972. Growth of larval herring (Clupea harengus) in the Bay of Fundy and Gulf of Maine. J. Fish. Res. Board Can., 29: 573-575

DRAGESUND, O., and O. NAKKEN. 1971. Mortality of herring during the early larval stage in 1967. ICES Rapp. Proc.-Verb., 160: 142146.

1973. Relationship of parent stock size and year-class 
strength in Norwegian spring spawning herring. ICES Rapp. Proc.-Verb., 164: 15-29.

DRAPEAU, G. 1973. Sedimentology of herring spawning grounds on Georges Bank. ICNAF Res. Bull, 10: 151-162.

GAMBLE, J. C. P. MaCLACHLAN, N. J. NICOLL, and I. G. BAXTER. 1981. Growth and feeding of Atlantic herring larvae reared in large plastic enclosures. ICES Rapp. Proc.-Verb., 178: 121-134.

GRAHAM, J. J. 1982. Production of larval herring, Clupea harengus, along the Maine coast, 1964-78. J. Northw. Atl. Fish. Sci, 3:63-85.

GRAHAM, J. J., and S. B. CHENOWETH. 1973. Distribution and abundance of larval herring. Clupea harengus harengus Linnaeus, over egg beds on Georges Bank. ICNAF Res. Bull., 10: 141-149.

GRAHAM, J. J., and C. W. DAVIS. 1971. Estimates of mortality and year-class strength of larval herring in western Maine, 1964-67. ICES Rapp. Proc.-Verb. 160: 147-152.

GRAHAM, J. J., S. B. CHENOWETH, and C. W. DAVIS. 1972. Abundance, distribution, movements and lengths of larval herring along the western coast of the Gulf of Maine. Fish. Bull. U.S., 70: 307-321.

GRAHAM, J. J., C. W. DAVIS, and B. C. BICKFORD. MS 1973. Autumnal distribution, abundance and dispersion of larval herring, Clupea harengus harengus Linnaeus, along the western coast of the Gulf of Maine in 1972. ICNAF Res. Doc., No. 12, Serial No. 2914, $33 \mathrm{p}$

GRIMM, S. K. 1983. Changes in time and location of herring, Clupea harengus $L$.. spawning relative to bottom temperature in the Georges Bank and Nantucket Shoals areas, 1971-77. NAFO Sci. Coun. Studies, 6 : 15-34.

GRIMM, S. K., W. MASTO, and M. PASTUSZAK. MS 1975. Report on larval herring distribution in the Gulf of Maine and on Georges Bank, 27 September-18 October 1974. ICNAFRes. Doc., No. 109, Serial No $3602,17 p$.

GROSSLEIN, M. D., R. W. LANGTON, and M. P. SISSENWINE. 1980. Recent fluctuations in pelagic fish stocks of the Northwest Atiantic, Georges Bank region, in relation to species interactions. ICES Rapp Proc.-Verb., 177: 374-404.

HENDERSON, P. A., J. W. WHITEHOUSE, and G. H. CARTWRIGHT. 1984. The growth and mortality of larval herring. Clupea harengus L., in the River Blackwater estuary, 1978-1980. J. Fish. Biol., 24: 613-622.

HOUDE, E. D. 1977. Abundance and potential yield of the round herring, Etrumeus teres, and aspects of its early life history in the eastern Gulf of Mexico. Fish. Bull. U.S., 75: 61-89.

HUNTER, J.R. (ed.). 1976. Report of a colloquim on larval fish mortality and their relation to fishery research, January 1975. NOAA Tech. Rep. NMFS Circ., 395, 5 p.

ICES. MS 1984. Report of the ad hoc working group on mackerel egg surveys. ICES C.M. Doc., No. H:3, 31 p.

ICNAF. 197i. Report of Standing Committee on Research and Statisiics (STACRES). ICNAF Redbook, 1971(1): 43-54.

MS 1972. Working group on joint survey of larval herring in the Georges Bank-Gulf of Maine areas (ICNAF Divisions 4X,5Y and 5Z), 9-12 May 1972, Boothbay Harbor, Maine. ICNAF Res. Doc., No. 123 , Serial No. 2852,39 p.

1974. Report of Standing Committee on Research and Statistics (STACRES). ICNAF Redbook, 1974: 9-61.

1975. Report of second meeting of Environmental Working Group. ICNAF Redbook, 1975: 95-108.

JOAKIMSSON, G. MS 1978. On the occurrence and distribution of fish larvae on Georges Bank and Nantucket Shoals in November 1972-77 (1976 excluded). ICES C.M. Doc., No. L:39, 28 p.

JOHANNESSEN, A. MS 1983. Abundance, distribution and mortality of herring larvae (Clupea harengus $L$.) in Lindaaspollene, western Norway. In Recruitment studies of herring, D.Sc. Thesis, Dept. Fish. Biol. Univ. Bergen, Norway, p. 1-63.

L.HERROU, $R$, and D. BRIAND. MS 1972. Distribution of herring larvae on Georges Bank and in the Guif of Maine in September 1971. ICNAF Res Doc., No. 62, Serial No. $2779,14 \mathrm{p}$.

LIMEBURNER, R., and R. C. BEARDSLEY. 1982. The seasonal hydrography and circulation over Nantucket Shoals. J. Mar. Res., 40: (suppl.): $371-406$

LOUGH, R. G. MS 1976a. Mortality and growth of Georges Bank-Nantucket Shoals herring larvae during three winters. ICES C.M. Doc., No. L:37. 25 p.
MS 1976b. The distribution and abundance, growth and mortality of Georges Bank-Nantucket Shoals herring larvae during the 1975/76 winter period. ICNAF Res. Doc. No. 123, Serial No. 4004, $30 \mathrm{p}$.

LOUGH, R. G., and G. R. BOLZ. MS 1979. A description of the sampling methods, and larval herring (Clupea harengusL.) data report for surveys conducted from 1968 to 1978 in the Georges Bank and Gulf of Maine areas. U.S. Nat. Mar. Fish. Serv., Northeast Fisheries Center, Woods Hole, Lab. Ref. Doc., No. 79-60, 230 p.

LOUGH, R. G., G. R. BOLZ, M. D. GROSSLEIN, and D. C. POTTER. 1981. Abundance and survival of sea herring (Clupea harengus L.) larvae in relation to environmental factors, spawning stock size, and recruitment for the Georges Bank area, 1968-1977 seasons. ICES Rapp. Proc-Verb., 178: 220-222.

LOUGH, R. G., M. PENNINGTON, G. R. BOLZ, and A. A. ROSENBERG. 1982. Age and growth of larval Atlantic herring, Clupea harengus $\mathrm{L}$., in the Gulf of Maine-Georges Bank region based on otolith growth increments. Fish. Bull. U.S., 80: 187-199.

MARAK, R. R., and J. B. COLTON. 1961. Distribution of fish eggs and larvae, temperature and salinity in the Georges Bank-Gulf of Maine area, 1953. Spec. Sci. Rep. U. S. - Fish., 398, 61 p.

MARAK, R. R., J. B. COLTON, and D. B. FOSTER. 1962a. Distribution of fish eggs and larvae, temperature and salinity in the Georges Bank-Gulf of Maine area, 1955. Spec. Sci. Rep. U.S. Fish. Wildl. Serv., - Fish., 411, 66 p.

MARAK, R. R., J. B. COLTON, D. B. FOSTER, and D. MILLER. 1962b. Distribution of fish eggs and larvae, temperature and salinity in the Georges Bank-Gulf of Maine area, 1956. Spec. Sci. Rep. U.S. Fish. Wildl. Serv., - Fish., No. 412, 95 p.

MAY, R. C. 1974. Larval mortality in marine fishes and the critical period concept. In The early life history of fish, J. H. S. Blaxter (ed.), Springer-Verlag, Berlin, p. 3-19.

MCKENZIE, R. A. 1964. Observations on herring spawning off southwest Nova Scotia. J. Fish. Res. Board Can., 21: 203-205.

MINET, J. P., G. PAULMIER, and J. C. POULARD. MS 1974. Distribution of larval herring on Georges Bank and off southern Nova Scotia, September 1973. ICNAF Res. Doc., No. 57, Serial No. 3270 , $18 \mathrm{p}$.

NOSKOV, A. S., A. L. NOVIKOV, and A. N. ROMANTCHENKO. MS 1977. Results of distribution and abundance survey of herring larvae in the Georges Bank area in September-October 1975. ICNAF Res. Doc., No. 43, Serial No. 5068, 14 p.

$\phi \mid E S T A D, V$., and E. MOKSNESS. 1981. Study of growth and survival of herring larvae (Clupea harengus $L$.) using plastic bag and concrete basin enclosures. ICES Rapp. Proc.-Verb., 178: 144-149.

PANKRATOV, A. M., and I. K. SIGAJEV. 1973. Studies on Georges Bank herring spawning in 1970. ICNAF Res. Bull, 10: 125-129.

PASTUSZAK, M., W. R. WRIGHT, and D. PATANJO. 1982. One year of nutrient distribution in the Georges Bank region in relation to hydrography, 1975-1976. J. Mar. Res., 40(suppl.): 525-542.

PAULMIER, G., and D. BRIAND. MS 1975. Environment and distribution of herring larvae on Georges Bank and the Nova Scotia Shelf in September 1974. ICNAF Res. Doc., No. 71, Serial No. 3555, 22 p.

PENNINGTON, M. 1983. Efficient estimators of abundance for fish and plankton surveys. Biometrics, 39: 281-286.

POSGAY, J. A., and R. R. MARAK. 1980. The MARMAP bongo zooplankton samplers. J. Northw. Atl. Fish. Sci., 1: 91-99.

SAVILLE, A. 1965. Factors controlling dispersal of the pelagic stages of fish and their influence on survival. ICNAFSpec. Publ., 6: 335-348.

SAVILLE, A., and D. SCHNACK. 1981. Overview: some thoughts on the current status of studies of fish egg and larval distribution and abundance. ICES Rapp. Proc.-Verb., 178: 153-157.

SCHNACK, D. MS 1974. Summary report of the 1973 ICNAF joint larval herring surveys in Georges Bank-Gulf of Maine areas. ICNAFRes. Doc., No. 105, Serial No. 3341, 23 p.

MS 1975. Summary of the ICNAF joint larval herring surveys in Georges Bank-Gulf of Maine areas, September-December 1974. ICNAF Res. Doc., No. 112, Serial No. 3605, 23 p.

SCHNACK, D., and W. T. STOBO. MS 1973. ICNAF joint larval herring surveys in Georges Bank-Gulf of Maine areas in 1972 - preliminary summary. ICNAF Res. Doc., No. 115, Serial No. 3081, 55 p.

SETTE, O. E., and E. H. AHLSTROM. 1948. Estimation of abundance of the eggs of the Pacific pilchard (Sardinops caerulea) off southern 
California during 1940 and 1941. J. Mar. Res., 7: 511-542.

SHERMAN, K. 1980. MARMAP, a fisheries ecosystem study in the Northwest Atlantic: fluctuations in ichthyoplankton-zooplankton components and their potential impact on the system. In Advanced concepts in ocean measurements for marine biology, $F$. P. Diemar, F. J. Vernberg, and D. Z. Mirkes (eds.), Belle W. Baruch Institute for Marine Biology and Coastal Research, Univ. S. Carolina Press, Columbia, S.C., p. 9-37.

SHERMAN, K., and L. EJSYMONT. MS 1976. The Polish plankton sorting and identification center to support fishery assessment investigations. ICNAF Res. Doc., No. 115, Serial No. 3938, 5 p.

SHERMAN, K., J. GREEN, and E. COHEN. MS 1976a. Variations in subsampling of zooplankton from the ICNAF area. ICNAF Res. Doc., No. 81, Serial No. 3893, 4 p.

SHERMAN, K., J. B. COLTON, R. BYRON, and J. BURNS. MS 1976b. Interim sorting protocol for ICNAF zooplankton samples. ICNAF Res. Doc., No. 84, Serial No. 3896, $6 \mathrm{p}$

SISSENWINE, M. P., and G. T. WARING. MS 1980. Status of sea herring fisheries of the Gulf of Maine-Georges Bank region. U.S. Nat. Mar. Fish. Serv., Northeast Fisheries Center, Woods Hole, Lab. Ref. Doc., No. 80-09, 7 p.

STOBO, W. T., and T. D. ILES. MS 1973. Larval herring distribution in the Bay of Fundy. ICNAF Res. Doc., No. 93, Serial No. 3051, 9 p.

THEILACKER, G. H. 1980. Changes in body measurements of larval northern anchovy, Engraulis mordax, and other fishes due to handling and preserviation. Fish. Bull. U.S., 78: 685-692.

TIBBO, S. N., and J. E. H. LEGARE. 1960. Further study of larval herring (Clupea harengus $L$.) in the Bay of Fundy and Gulf of Maine. J. Fish. Res. Board Can., 17: 933-942.

TIBBO, S. N., J. E. H. LEGARÉ, L. W. SCATTERGOOD, and R. F. TEMPLE. 1958. On the occurrence and distribution of larval herring (Clupea harengus L.) in the Bay of Fundy and the Gulf of Maine. J. Fish. Res. Board Can., 15: 1451-1469.

WOOD, R. J., and A. C. BURD. MS 1976. Growth and mortality of herring larvae in the central North Sea, ICES C.M. DoC., No. H:8, $18 \mathrm{p}$. 
